\title{
O Dibuk
}

The Dibbuk

\section{Cláudio Feldman*}

Santo André, Brasil

claudiofeldman@uol.com.br

A ética é a metafísica judaica.

(Waldo Frank)

O teatro popular ídiche, que compreende vasta produção entre comédias e dramas, tem uma de suas obras-primas em O Dibuk, de Sch.An-Ski (pseudônimo do escritor russo Schloime Zainvil Rapaport, 1863-1920). Esse clássico da dramaturgia reflete a essência de uma concepção judaica de vida. Ela não só descreve como vivem os judeus, mas também no que creem.

A peça talvez seja o texto, em ídiche, mais famoso no Ocidente, pois foi traduzida e representada em diversos idiomas. No Brasil, ela ganhou a versão do lúcido e competente Jacó Guinsburg, na edição Editora Perspectiva (aliás, citaremos alguns trechos dessa tradução); foi levada à cena várias vezes por artistas amadores e profissionais.

A alegoria, o realismo e o ritual (a música e a dança) se põem a serviço de observação penetrante. É uma história de amor e de crítica social. Cinge-se à tradição, ao mesmo tempo em que sugere atitudes revolucionárias. De tom lírico, seu conteúdo é ainda filosófico e humanista.

O drama começa com uma melodia mística, espécie de ouverture entoada na sinagoga, que antecipa o motivo dominante:

\author{
Por que, por que \\ do cimo das alturas, \\ caiu a alma \\ no mais profundo dos abismos? \\ A queda, em si mesma, \\ Contém a ressurreição...
}

A peça narra uma história de amor, ainda que os enamorados troquem só algumas poucas palavras. Eles permanecem completamente estáticos, observando-se mutuamente. Nem sequer a morte pode separá-los. O dibuk que possui Léa e fala por intermédio de sua boca é o espírito do desaparecido amado Hanã, que se recusa a

\footnotetext{
"Professor, escritor e roteirista. 


\section{Arquivo Maaravi}

abandoná-la e a deixar seu corpo. "Como pode, então, apagar-se para sempre a chama de uma vida que não ardeu até o fim? Como?", pergunta Léa, revelando, assim, o sentido da imortalidade.

Léa é a filha de um homem rico, de posses. Hanã, o estudante de Cabala de quem está enamorada e que a ama, é, ao contrário, muito pobre. Os preconceitos das pessoas acomodadas de sua comunidade conspiram para manter afastadas as duas almas puras.

Mas no seio de Léa se aninha a revolta. "Sou daqueles que buscaram novos caminhos", diz ela, falando pelo Autor e por sua geração. "Só aquele que se extraviou do caminho reto, busca novos caminhos", replica o rabino. "O caminho, contesta Léa, com a voz de seu amado morto (o dibuk), é muito estreito."

O rabino, apesar de ser um personagem bem delineado, se consome em dúvidas. Quando lhe anunciam que o pai de Léa precisa de seus préstimos para exorcizar o dibuk que a possui, exclama: "A mim?... A mim? Como pôde vir a mim, se o meu 'eu' desapareceu..." Seu assistente o tranquiliza: "Rabi, o mundo todo vem a vós." Então o contesta o venerável homem: "O mundo todo... Mundo cego... Ovelhas cegas seguem a um pastor cego... Pois, se cegos não fossem, não viriam a mim, mas dirigirse-iam àquele que pode dizer 'eu', ao único 'Eu' do mundo'.

O rabino assinala como causa da impureza de Léa o orgulho de seu pai, com estas palavras: "O verme só penetra na fruta quando esta começa a apodrecer" e, mais adiante: "Às vezes, os filhos são punidos pelos pecados dos pais." Por fim, decreta que o pai de Léa doe a metade de sua fortuna aos necessitados.

Muito mais profundas, e revolucionárias em outro sentido, são as passagens nas quais Hanã diz: “Não combater o pecado, e, sim, redimi-lo [...] assim é preciso purgar o pecado de suas impurezas, para que nele reste apenas santidade." Um companheiro exclama: "Santidade no pecado?" Hanã responde: "Tudo o que Deus criou contém algo de santidade..." "O pecado, admoesta o amigo, não foi obra de Deus, mas de Satã." Hanã argumenta: "E quem criou Satã? Deus, também. Satã é o nome do outro aspecto de Deus. E por ser um aspecto de Deus, Satã contém em si, necessariamente, santidade."

Desse modo, chegamos à essência da moralidade e da metafísica judaica: uma total aceitação da vida dentro de um contexto de perpétua luta, de maneira tal que "a queda encerra em si mesma a ressurreição". Esse otimismo só provém do reconhecimento do mal.

Recebido em: 17/02/2018.

Aprovado em: 18/03/2018. 